\title{
European Cohesion Policy and Evaluating the Impact of Evidence-Based Policy
}

\author{
Laura Južnik Rotar \\ University of Novo mesto Faculty of Economics and Informatics \\ Stanko Trček \\ University of Novo mesto Faculty of Economics and Informatics
}

\begin{abstract}
In the 2014-2020 programming period, the cohesion policy focuses more on results and evaluation of programs based on facts. Due to the Commission policies, an expansion of cohesion policy counterfactual impact evaluation of programmes with new approaches can be expected in the future. In this paper, the focus is on the calculation of the impact of received European cohesion funds on the revenue of companies in Slovenian municipalities one/two years after the receipt of cohesion funds for the 2007-2013 period. Two development priorities that affect company revenue - Enterprise competitiveness and research excellence and Promoting entrepreneurship and adaptability are considered. The effect of the use of the European cohesion funds on company revenue in Slovenian municipalities is positive for 2009 and 2010 and negative for all other years examined. The results of the research can serve to policy-makers to reduce the economic, social and territorial disparities in less developed European countries and regions therefore reaching balanced regional development.
\end{abstract}

Keywords: European cohesion policy, policy impact evaluation, regional development, difference in differences approach

Paper type: Research article

Received: 8.1.2021.

Accepted: 27.1.2021.

DOI: $10.2478 /$ crdj-2021-0008 


\section{Introduction}

The European cohesion policy aims to reduce disparities in development between the European Community member states. The cohesion policy is a part of the European Union regional policy, the main EU investment policy that includes almost a third of the entire EU budget. The cohesion funds are intended for less developed EU countries or regions within EU countries. They are intended to address economic, social and territorial disparities. Cohesion funds played an important role at the onset of the financial crisis in 2007. Historically, the European cohesion policy can trace its foundations to the political commitment written down in the Treaty establishing the European Economic Community in 1957 - the Treaty of Rome. Acquisition of funds from the cohesion policy is very important for the recipient countries because these funds represent a large and immediate cash flow. It is therefore in the interest of the recipient countries of the European cohesion funds to completely draw the funds available to them in various funds. Implementation of the cohesion policy is legally standardized and administratively regulated. Due to the amount of funds, drawing on cohesion funds is under the supervision of competent state authorities, EU bodies, the politics and the public. The cohesion policy is objectiveoriented and through various funds, provides concrete objectives that should help reduce disparities between the EU member states (European Commission, 2014). Based on the objectives set, various projects are being financed. Only project results can bring the desired changes that are required to reduce disparities between regions and countries. Successful drawing on cohesion funds itself does not ensure that the objectives of the cohesion policy are being met. Cohesion policy objectives are realized through the effects of successfully implemented projects within the framework of the set programmes and policies. One may ask if the implemented projects have an actual effect and result in desired changes that are the goal of the cohesion policy. In the legal basis, the European Commission lays down monitoring and evaluation of the cohesion policy. The legal basis of the European Commission is supplemented by instructions and methodological guidance regarding the implementation of programme monitoring and evaluation (see, for example European Commission 2013a, 2013b, 2014).

Methods for assessing the impact of evidence-based policy-making allow for impact assessment of implemented programmes and represent the orientation of the European Commission in the new programming period 2021-2027 (Caliendo et al., 2010). Gertler et al. (2016) state that impact assessment of programmes is a part of a broader trend of policy-making based on facts and a transfer from the focus on input programme parameters to output programme results.

This paper focuses on the European cohesion policy and participation of Slovenia in the 2007-2013 programming period. Taking into account the modern guidelines for evaluation of impacts of evidence-based policy-making in the research, authors focused on evaluation of the impact of drawing on cohesion funds on local companies in 2007-2013 period one/two years after the receipt of cohesion funds. The aim of the research is to estimate the effect of absorption from European cohesion funds in Slovenian municipalities based on the companies' revenue of the mentioned municipalities. Two development priorities that affect company revenue - Enterprise competitiveness and research excellence and Promoting entrepreneurship and adaptability are considered. For this, authors used the difference in differences method, which is one of the proposed econometric method to use for counterfactual impact evaluation by Commission and by modern literature in the field of programme evaluation (see, for example Srhoj et al., 2020, de Jong et al., 2020).

The findings of our research have both theoretical and practical implications. It is believed that the findings of this research enable better understanding of the complexity of the European cohesion policy and methodological issues connected with counterfactual 
impact evaluation and causal effect. Our research adds to the relatively thin literature in the relation of using econometrics approaches in the evaluation of the effectiveness of cohesion programmes. Above all, the research contributes to the raised awareness about evidence-based policy-making and the need to evaluate programmes in order to effectively distribute funds, especially in times of tight budgets. What is more, the results of the research can serve to policy-makers when taking decisions about certain programmes and in such a way contribute to more effective allocation of production factors, which can increase productivity, economic growth and, furthermore, prosperity in society.

The rest of the paper is organized in the following manner. After this introduction, Section 2 describes the European cohesion policy and participation of Slovenia in the 2007-2013 programming period. Section 3 reviews literature. Section 4 describes methodology and Section 5 results and discussion, while Section 6 concludes.

\section{Literature review}

The example of using the difference in differences method in combination with the method of matching in the economic sphere is used in the Evaluation of Implementation of Entrepreneurship and Competitiveness Policy in the 2004-2009 Period research project. Jaklič (2012) analyses the effect of received entrepreneurial incentives on performance through sales growth, employment, added value and some other indicators. Using the difference in differences method and forming the control group using matching, the analysis gives an assessment of the impact of voucher incentives on companies and sole proprietors.

In the case of evaluation of EU programmes for rural development (Special accession programme for agriculture and rural development) for Slovakia and Poland, Michalek (2012) uses the difference in differences method in combination with the method of matching. The evaluation shows the impact calculation of the SAPARD programme for Poland and Slovakia according to the NUTS-4 classification in the 2002-2005 period. The author points out that most of the quantitative assessments of rural development programmes in the 2000-2006 period use a so-called naive approach using basic evaluation methodologies. The control groups are mostly assembled without the process of matching with experimental groups, which leads to biased results. Michalek also notes that by the end of $2010,75 \%$ of evaluations sent to the European Commission were performed without taking into account the counterfactual approach.

For the European Social Fund in the 2014-2020 period, the Commission established a set of output and result indicators at the level of each beneficiary (European Commission, 2012). The level of micro data will allow for a more robust analysis and monitoring of programmes of this fund. In 2013, the Directorate-General for Employment, Social Affairs and Inclusion at the Commission supported eight pilot studies of counterfactual impact evaluation for European Social Fund programmes (Elia et al., 2015). Of eight assessments, the difference in differences method in combination with the matching method was used in three cases. The study in the Castilla-La Mancha region in Spain considered the impact of training for specific skills for unemployed young people up to 24 years of age. Eighteen months after the start of training, young people that were included in the additional training programme had a $12 \%$ higher probability of employment, retained employment for a longer time and concluded more employment contracts than those that were not included in the programme. The study of the impact of adult vocational education in Estonia was performed using two methods - the method of matching and a combination of the method of matching and the difference in differences method. Within the framework of the method of matching, the adults included in education had a $6 \%$ higher probability of 
employment and future income than those that were not included in this education. A calculation using a combination of the method of matching and the difference in differences method showed a statistically insignificant impact on employability and an impact on the amount of income in the amount of 5 percentage points. In Lithuania, five active employment policy projects were carried out between June 2008 and November 2013, which included 70 thousand various beneficiaries belonging to risk groups. The programmes provided two types of assistance - financial incentives for employers and inclusion in vocational training. The study measured the number or registered days of unemployment in a year, the number of days of employment in a year, total annual income and average daily income. Calculations have shown that in short term (one year after intervention), financial incentive programmes are successful in terms of both employment duration and income. Two years after the intervention, results are less beneficial, but still very positive. One and two years after the programme, the effect regarding inclusion in vocational training is negative both in terms of probability of employment and future income. The reason is supposed to be the closure effect, as well as the fact that effects will only be felt over a long period.

\section{The European Cohesion Policy and Participation of Slovenia in the 2007- 2013 Programming Period}

\section{Structural and Cohesion Funds}

The regional policy is the main EU investment policy that includes almost a third of the entire EU budget. The cohesion policy is a part of the European Union regional policy. The European cohesion policy supports solidarity and aims to reduce disparities in development between the European Community member states. A breakdown of cohesion policy funds shows that a large part of cohesion funds $-€ 179.4$ billion from the total of $€ 351.8$ billion - is intended for less developed regions to address economic, social and territorial disparities within the EU. Regional policy funds are included in different funds. The main three funds include the European Regional Development Fund (ERDF), the Cohesion Fund (CF) and the European Social Fund (ESF). The European Regional Development Fund (ERDF) supports regional economic and social cohesion. It promotes programmes that strengthen economic growth, competitiveness and job creation. The Cohesion Fund is intended for the environment, sustainable development and connectivity in countries. The European Social Fund is people-oriented and allows for better education and employment opportunities and helps reduce poverty and social exclusion. In addition to the above three funds, funds are also included in the European Agricultural Fund for Rural Development (EAFRD) and the European Maritime Fisheries Fund (EMFF). All the listed funds form the European Structural and Investment Funds (ESI).

Regional policies are formed for the period of seven years. These periods are named programming period or financial perspectives. Different programming periods have different objectives. The current 2014-2020 cohesion policy-programming period has five main areas, namely employment, research and development, education, social inclusion and climate/energy. Within the framework of commonly agreed objectives at the EU level, each member country concludes a partnership agreement and operational programmes 
with the European Commission, specifying investment priorities and development objectives. For the 2014-2020 programming period, the cohesion policy is based on eleven thematic objectives that support growth. Compared with the previous period, the 2014-2020 period is focused on results with measurable objectives. Total assets of the European cohesion policy at the EU level amount to almost $€ 352$ billion, which is slightly more than $32 \%$ of the entire EU budget for this period. Implementation of the European cohesion policy requires that projects financed from cohesion funds be co-financed from public and private sources, which further increases the overall financial impact of the cohesion policy. Acquisition of funds from the cohesion policy is very important for the recipient countries because these funds represent a large and immediate cash flow. Due to the amount of funds, drawing on cohesion funds is under the supervision of competent state authorities, EU bodies, the politics and the public.

\section{Participation of Slovenia in the 2007-2013 Period}

In the process of becoming a full member of the EU, Slovenia used pre-accession funds. After becoming a full member of the EU in 2004, Slovenia used a part of the funds included in the programming period ending in 2006. At the end of 2015, payments of European cohesion funds for the 2007-2013 programming period are being finalized, with Slovenia fully participating in this period. During this period, the European budget provided funds in the amount of $€ 4.1$ billion for Slovenia from the Structural and Cohesion Funds. European cohesion funds are important for the Slovenian budget. Available cohesion funds are increasing within the programming period and in respect of all state budget revenues, from slightly more than $4 \%$ of the budget at the beginning of the financial perspective in 2007 to more than $11 \%$ of the budget at the end of 2011 (Računsko sodišče Republike Slovenije, 2008).

The legal basis for drawing funds are operational programmes that provide concrete objectives, development priorities, beneficiaries and the financial breakdown of funds. The EU cohesion policy for the 2007-2013 period had three operational programmes covering the field of regional development (OPRR, 2008), the field of human resources development (OPRČV, 2008 ) and the field of environmental and transport infrastructure (OPROPI, 2008).

The Operational Programme for Strengthening Regional Development Potentials (OPRR) is focused on development of regions and on competitive, knowledge-based economy. Beneficiaries include companies, state and municipalities, educational institutions, public and private institutions and associations, non-profit and non-governmental organisations. The programme is divided into five development priorities and the EU funds in the amount of $€ 1.78$ billion are drawn from the European Regional Development Fund (ERDF). The largest share of EU funds in the amount of $€ 619,442,634(35 \%)$ is dedicated to the "Development of Regions" priority. EU funds in the amount of $€ 613,152,895$ (34\%) are intended for the "Competitiveness and Research Excellence" priority. The main objective of the Human Resources Development Operational Programme (OPRČV) is investment into building human capital, which will ensure a higher level of innovation and consequently greater employability, social inclusion and reduction of regional disparities. The programme is divided into six development priorities and the EU funds in the amount of $€ 755.9$ million are drawn from the European Social Fund (ESF). The total financing amount of the OPRČV operational programme is $€ 889,058,088$. The largest share of EU funds in the amount of $€ 262,114,965$ is intended for the "Promotion of Entrepreneurship and Flexibility" development priority. The objective of the Development of Environment and Transport Infrastructure operational programme (OPROPI) is to ensure infrastructure in the field of environment and transport. The programme is divided into six development 
priorities, with EU funds in the amount of $€ 1.56$ billion drawn from the Cohesion Fund and - in a small part - from the ERDF.

\section{Success of Absorption of EU Cohesion Funds}

The objective of beneficiary countries entitled to EU cohesion funds is maximum utilization of allocated cohesion funds. Information on the use of EU funds as of 31 December 2015 indicates that Slovenia paid $€ 4,312,527,143$ from its budget for all three operational programmes, which is $105.16 \%$ of available EU funds. By the end of 2015, Slovenia issued claims in the amount of $€ 3,951,547,309$ to the European Commission, which amounts to $96.4 \%$ of available funds. Rules on payment of cohesion funds state that the European Commission reimburses up to $95 \%$ of used funds, with the remaining $5 \%$ of funds being reimbursed when the beneficiary country receives the final report on the implementation of operational programmes for the 2013-2017 period (Služba vlade Republike Slovenije za razvoj in evropsko kohezijsko politiko, 2016). Within the framework of the ERDF, ESF and CF, more than 5000 projects were financed in the 2007-2013 programming period.

\section{Methodology}

\section{Research Objectives and Data}

Taking into account the modern guidelines for evaluation of impacts of evidence-based policy-making in the research, the focus is on evaluation of the impact of drawing on cohesion funds on local private companies using the difference in differences method in 2007-2013 period. The aim of the research is to estimate the effect of absorption from European cohesion funds in Slovenian municipalities based on the companies' revenue of the mentioned municipalities. When calculating the effect of received cohesion funds on company revenue, authors took into account two development priorities that affect company revenue - Enterprise competitiveness and research excellence and Promoting entrepreneurship and adaptability. The Enterprise competitiveness and research excellence development priority programme provides for an average increase in value added in the amount of $8-10 \%$ per employee in companies that have received cohesion funds (Služba vlade Republike Slovenije za razvoj in evropsko kohezijsko politiko, 2016). It is believed that the increased value added per employee will be indirectly reflected in an increased company revenue. Company revenue which is used as aggregate value is information that is easily accessible at the level of municipalities for individual years. The data source is the Statistical Office of the Republic of Slovenia. The Promoting entrepreneurship and adaptability development priority programme is aimed at investing in human resource development and the integration of economic, educational, research, development and employment spheres. This development priority is complementary with the Enterprise competitiveness and research excellence development priority of the OPRR programme. Among the indicators of this development priority, the transfer of 115 new applicative technologies, patents or innovations to meet the needs of the economy as a result of supported activities is planned. Authors expect that the transfer of new technologies to the economy will also result in an increased company revenue.

Authors assessed the impact of received European cohesion funds on the revenue of companies in Slovenian municipalities one/two years after the receipt of cohesion funds to 
assess short and long term impact of funds mentioned. Table 1 shows company revenue according to the Slovenian statistical regions in the 2008-2014 period. Due to the impact of the economic crisis, company revenue in all statistical regions declined. The Gorenjska and Goriška regions experienced a declining trend of company revenue in the examined period.

\section{Table 1}

Company revenue according to regions (in EUR 1000)

\begin{tabular}{|l|c|c|c|c|c|r|r|}
\hline Region & \multicolumn{1}{|c|}{2008} & \multicolumn{1}{c|}{2009} & \multicolumn{1}{c}{2010} & \multicolumn{1}{c}{2011} & \multicolumn{1}{c}{2012} & \multicolumn{1}{c}{2013} & 2014 \\
\hline Pomurska & $2,680,297$ & $2,300,870$ & $2,305,183$ & $2,465,324$ & $2,614,531$ & $2,586,961$ & $2,859,623$ \\
\hline Podravska & $10,955,344$ & $9,192,508$ & $9,632,117$ & $10,092,168$ & $9,863,598$ & $9,921,337$ & $10,293,275$ \\
\hline Koroška & $2,283,660$ & $1,752,658$ & $1,840,289$ & $2,058,025$ & $2,020,237$ & $1,955,144$ & $2,021,142$ \\
\hline Savinjska & $9,910,320$ & $8,588,906$ & $8,873,675$ & $9,460,098$ & $9,154,901$ & $9,184,229$ & $9,309,987$ \\
\hline Zasavska & $1,116,882$ & 970,626 & 994,722 & $1,042,167$ & 998,605 & 963,957 & 955,826 \\
\hline Posavska & $2,152,332$ & $2,096,181$ & $2,255,247$ & $2,781,540$ & $3,224,940$ & $2,981,247$ & $3,097,998$ \\
\hline JV Slovenija & $5,961,848$ & $5,422,208$ & $5,728,914$ & $5,685,051$ & $5,444,639$ & $5,153,152$ & $5,452,396$ \\
\hline $\begin{array}{l}\text { Osrednje } \\
\text { slovenska }\end{array}$ & $42,212,232$ & $37,578,755$ & $39,013,388$ & $40,528,042$ & $41,115,868$ & $41,636,035$ & $42,626,496$ \\
\hline Gorenjska & $7,185,300$ & $5,822,294$ & $6,213,259$ & $6,437,932$ & $6,456,508$ & $6,340,948$ & $6,700,737$ \\
\hline Primorska & $1,303,637$ & $1,120,466$ & $1,209,091$ & $1,278,751$ & $1,255,205$ & $1,299,626$ & $1,431,246$ \\
\hline Goriška & $4,448,113$ & $3,670,648$ & $3,885,528$ & $4,028,942$ & $3,837,850$ & $3,709,795$ & $3,852,123$ \\
\hline Obalnokraška & $5,576,322$ & $4,544,093$ & $4,753,790$ & $4,931,631$ & $4,752,540$ & $4,893,092$ & $4,970,940$ \\
\hline (all) & $95,786,287$ & $83,060,213$ & $86,705,203$ & $90,789,671$ & $90,739,422$ & $90,625,523$ & $93,571,789$ \\
\hline
\end{tabular}

Source: Statistical Office of the Republic of Slovenia, Slovene Statistical Regions and Municipalities in numbers.

Control group formation is essential to meet the assumption of conditional independence, which ensures the best possible correlation between the control group and the experimental group. Ideally, both groups would differ only in receiving the intervention and the difference between the groups would only be the result of intervention. In our research, municipalities that did not receive European cohesion funds in a given year, are assigned to the control group during the observational period, whilst the municipalities that have received the European cohesion funds, are assigned to the experimental group. The causal effect assessment is performed with the $\mathrm{R}$ open-source programme. Within the framework of this programme, the Matchlt package was used (Ho et al., 2007), which allows us to prepare data and form the control group.

The data necessary for calculation include a combination of variable values and dummy variables marking the period and the group. The data for the company income variable by municipalities and years was obtained from the Statistical Office of the Republic of Slovenia. Other data sources include data on payment of cohesion funds by municipality, operations, development priorities and year. The data source for paid cohesion funds is the ISARR information system. The administrator of the ISARR information system is the Slovenian Government Office for Development and European Cohesion Policy, which acts as the managing authority in Slovenia. Information on the disbursement of cohesion funds is publicly accessible via the EU funds website.

Both sources of data are merged using common variables - municipality and year. A particular problem in the preparation of this data were missing municipality codes in the 
data on allocated cohesion funds, which are crucial for our analysis. Merging of data on cohesion funds with the municipality register using municipality names was not successful. The reason for this was in differently entered municipality names. Because merging of data using the municipality register was essential, authors had to write a programme to harmonize municipality names with the municipality names in the municipality register. After this, authors indirectly obtained municipality codes from the Statistical Office of Slovenia register. In order to organize data on cohesion funds, programming was required because manual editing of municipality names would be very time-consuming due to the database size. It would be very appropriate for analytical data processing if institutions published data in the universal text format, which is more suitable for further use in software tools.

\section{The Difference in Differences Approach}

The difference in differences method is used to measure the treatment impact (causal effect), carried out in the experimental group. Under treatment, introduction of a new measure, policy or intervention over a certain group can be included. The observed variable was measured in two periods. The variable value was measured in the period before the treatment and in the period after the treatment. The difference in value of the observed variable before and after the treatment can be attributed partially to the treatment and partially to other unexplained factors. The entire difference in value of the variable therefore cannot be attributed solely to the treatment (Angrist et al., 1996; Cameron et al., 2005; Wooldridge, 2010). Along with the experimental group, the method includes a control group, which did not receive any treatment. The control group is used to compare the value of the observed variable in the time before and after the treatment. The value of the dependant variable in the experimental and the control group is different in the starting and the ending period. However, the interest is in the difference in the difference between the starting and the ending period, which is the result of the received treatment. The idea of the method is that the groups are the same in all aspects, with the exception of the treatment received by the experimental group (see, for example Južnik Rotar 2012, 2019; Khandker et al., 2010; Lee, 2005). The decisive assumption for this assertion is that both groups have the same trend. The assumption of the same trend means that both groups move in a tandem and that the difference between the groups without the intervention in the starting and the ending period would be the same. The assumption allows for us not knowing or controlling all the factors that influence the result. The only important thing is that the factors are fixed during the intervention. The input data structure required for calculation of difference in differences uses three variables, which are described in Table 2.

\section{Table 2}

Variables required for calculation of difference in differences

\begin{tabular}{|l|l|}
\hline Variable & Description \\
\hline $\mathrm{y}$ & $\mathrm{y}$ marks the measured variable (such as income of companies) \\
\hline $\mathrm{t}$ & $\begin{array}{l}\mathrm{t} \text { marks the period of measuring the variable } \mathrm{Y} ; \text { the value } \mathrm{t}_{0} \text { represents } \\
\text { the starting period and } \mathrm{t}_{1} \text { represents the ending period }\end{array}$ \\
\hline $\mathrm{i}$ & $\begin{array}{l}\text { i marks the group where the variable y belongs; } \mathrm{i}_{0} \text { represents the control } \\
\text { group and } \mathrm{i}_{1} \text { represents the experimental group }\end{array}$ \\
\hline
\end{tabular}

Source: own research. 
The results of individual calculation elements of difference in differences are presented in tabular form, as shown in Table 3.

\section{Table 3}

Calculation of difference in differences

\begin{tabular}{|l|l|l|l|}
\hline & $\mathrm{i}_{0}$ & $\mathrm{i}_{1}$ & difference \\
\hline $\mathrm{t}_{0}$ & A & C & C - A \\
\hline $\mathrm{t}_{1}$ & B & D & D - B \\
\hline difference & B - A & D - C & $(D-B)-(C-A)$ \\
\hline
\end{tabular}

Source: own research.

\section{Cohesion Funds Allocation Process}

Competence, responsibilities and duties of participants in the procedures of planning and spending of European cohesion policy funds are detailed in the Decree on the implementation of procedures for the use of the European cohesion policy funds in the Republic of Slovenia in the programming period 2007-2013. The Decree defines the basic concepts, roles and participants in the procedure of cohesion policy implementation. For each participant type, their competence, responsibilities and duties in the procedure of cohesion policy implementation are listed. The cohesion policy implementation in Slovenia is centralized. Namely, the Slovenian Government Office for Development and European Cohesion Policy, which acts as the managing authority, is competent for the implementation of operational programmes. The managing authority transfers the implementation of some of the duties to other direct budget users, which act as so-called intermediate bodies. Intermediate bodies are individual ministries or public agencies, which cover individual fields. In the field of entrepreneurship development, the intermediate body is the Public Agency of the Republic of Slovenia for the Promotion of Entrepreneurship.

The allocation of cohesion funds is performed in two ways - through calls for tenders or direct confirmation of the operation. In the field of entrepreneurship, funds are always allocated through calls for tenders. Companies wishing to obtain cohesion funds apply to calls for tenders prepared by ministries or agencies for individual fields of the cohesion policy. The joint point for publication of calls for tenders in the field of the cohesion policy is the web portal, managed by the managing authority. Finding appropriate calls for tenders and tracking of the launch of calls is a time-consuming task. An application to calls for tenders is also a demanding administrative task, which many small companies are not able to carry out on their own. In addition to the application, the applicant needs to provide the entire project and investment documentation.

Individual calls to tender detail the object, purpose and objective of the call to tender, the beneficiaries and the conditions for applying to the call to tender. For selection of companies that have applied and meet the conditions in the call to tender, objective criteria for application assessment based on scoring are used. The criteria consist of individual sub-criteria, which are assessed with the highest possible number of points and are defined in detail in the tender. The call to tender specifies the amount of available funds and the possible dynamics of funds utilization throughout the years. The tendering authority issues a decision on co-financing to the selected applicants and enters into a contract on co-financing with the applicants. The use of acquired funds for the beneficiaries (companies) is strictly purposeful and defined in the call to tenders with 
eligible costs. Eligible costs defined in the call to tender depend on the individual policy covered by the call to tenders. The recipients of cohesion funds need to keep accounts, which allows control of the purposeful use of funds. Each project that acquires cohesion funds is subject to the verification of project implementation and purposeful use of funds.

\section{Results and Discussion}

The impact of received European cohesion funds on the revenue of companies in Slovenian municipalities one/two years after the receipt of cohesion funds was estimated. Table 4 shows the difference in differences estimates.

\section{Table 4}

Difference in differences estimates

\begin{tabular}{|c|c|c|c|}
\hline Time & Control group & Experimental group & Difference \\
\hline 2008 & 6.240 .659 & 89.545 .628 & 95.786 .287 \\
\hline 2009 & 5.378 .488 & 77.681 .725 & 83.060 .213 \\
\hline Difference & -862.171 & -11.863 .903 & -12.726 .074 \\
\hline 2008 & 6.240 .659 & 89.545 .628 & 95.786 .287 \\
\hline 2010 & 5.675 .507 & 81.029 .696 & 86.705 .203 \\
\hline Difference & -565.152 & -8.515 .932 & -9.081 .084 \\
\hline 2009 & 5.366 .215 & 77.693 .998 & 83.060 .213 \\
\hline 2010 & 5.728 .001 & 80.977 .202 & 86.705 .203 \\
\hline Difference & 361.786 & 3.283 .204 & 3.644 .990 \\
\hline 2009 & 5.366 .215 & 77.693 .998 & 83.060 .213 \\
\hline 2011 & 6.018 .103 & 84.771 .568 & 90.789 .671 \\
\hline Difference & 651.888 & 7.077 .570 & 7.729 .458 \\
\hline 2010 & 14.576 .173 & 72.129 .030 & 86.705 .203 \\
\hline 2011 & 15.654 .668 & 75.135 .003 & 90.789 .671 \\
\hline Difference & 1.078 .495 & 3.005 .973 & 4.084 .468 \\
\hline 2010 & 14.576 .173 & 72.129 .030 & 86.705 .203 \\
\hline 2012 & 15.675 .359 & 75.064 .063 & 90.739 .422 \\
\hline Difference & 1.099 .186 & 2.935 .033 & 4.034 .219 \\
\hline
\end{tabular}




\begin{tabular}{|l|r|r|r|}
\hline 2011 & 22.368 .068 & 68.421 .603 & 90.789 .671 \\
\hline 2012 & 22.119 .807 & 68.619 .615 & 90.739 .422 \\
\hline Difference & -248.261 & 198.012 & -50.249 \\
\hline & & & \\
\hline 2011 & 22.368 .068 & 68.421 .603 & 90.789 .671 \\
\hline 2013 & 22.260 .533 & 68.364 .990 & 90.625 .523 \\
\hline Difference & -107.535 & -56.613 & -164.148 \\
\hline
\end{tabular}

Source: own research.

The econometric difference in differences estimation reveals that the Enterprise competitiveness and research excellence and Promoting entrepreneurship and adaptability development priorities had a positive impact on company revenue in Slovenian municipalities one/two years after the receipt of cohesion funds only for 2009 and 2010; for all other years examined, the effect of drawing on cohesion funds is negative. Since the examined period coincides with the economic crisis, a reduction in economic activity, a decrease in demand and a drop in investments, the negative effect can be attributed to these reasons, but such effects also occur with a delay. The most obvious fall in real GDP per capita in Slovenia was in the years 2008/2009 when real GDP per capita felt down from 19200 EUR to 17600 EUR and then again in the year 2013 in comparison with the year 2008 when real GDP per capita was 17200 EUR (in comparison with 19200 EUR in the year 2008). In the struggle for competitive advantage, Slovenian companies are still faced with poor connection between the economic, educational, research, development and employment spheres. The transfer of new technologies, patents, and innovations to meet the needs of the economy is slower than in other comparable economies. The rigid legislation and an extensive administrative burden further aggravate the companies' ability for a faster adaptation to the changing economic conditions and thereby generation of higher revenue or business results.

The evaluation approach used in this paper supports the orientation of the European Commission in the new programming period towards evidence-based policy-making. The European Commission also encourages the Member States to follow this orientation and to increase efforts to develop credible evidence of the European policy effects which requires counterfactual impact evaluations. Counterfactual impact evaluations answer the question of what would the results be in the absence of the intervention. Counterfactual impact evaluations address the crucial question of causal inference and of what works. In the programming period 2014-2020 the focus is therefore towards a stronger performance and result orientation. Counterfactual impact evaluations provide evidence on net effects or impacts of interventions which is now a need and existing evaluation practice should be supplemented with efforts to develop credible evidence of the European policy (Ravallion, 2012). Our paper therefore supports this orientation and promotes development of the culture of evaluation. Orientation towards evidence-based policy-making is especially important in times when facing tight budget and effective use of public funds. Such evaluation approaches are needed to inform policy-makers on a range of decisions, from withdrawing inefficient programs, reallocating funds to effective programs, comparing and selecting among various program alternatives. Such evaluation approaches enable policymakers to assess the effectiveness of interventions, make comparisons between interventions and assess their relative performance. 


\section{Conclusion}

By moving the focus from drawing on cohesion funds to measurable programme results, greater opportunities for fact-based impact evaluation of the cohesion policy are opening. This movement of focus is supported by the European Commission in its legal basis and methodological guidelines. In its methodological guidelines, the Commission encourages the programme impact evaluation with approaches based on the counterfactual concept. In the research, the difference in differences method was used. The effect of the use of the European cohesion funds on company revenue in Slovenian municipalities is positive for 2009 and 2010 and negative for all other years examined. Authors associate the obtained results with the economic crisis because such effects may also occur with a delay. Despite this, Slovenian companies are still faced with poor connection between the economic, educational, research, development and employment spheres, while the transfer of new technologies, patents, and innovations to meet the needs of the economy is slower than in other comparable economies. A rigid legislation and administrative burdens present additional obstacles to companies. A new information system to support the cohesion policy implementation is in use from the mid-2017. It is assumed that a new information system will ensure quality data, which will be the basis for evaluation of the effects based on facts. With the increased availability and knowledge of methodologies, quality data, implementation of assessments based on facts in the field of cohesion policy can be expected.

\section{References}

Angrist, J.D., Imbens, G.W., Rubin, D.B. (1996). Identification of Causal Effects Using Instrumental Variables. Journal of the American Statistical Association, 91(434), 444-455.

Cameron, C.A., Trivedi, P.K. (2005). Microeconometrics. Methods and Applications. Cambridge: Cambridge University Press.

Caliendo, M., Falk, A., Kaiser, L.C., Schneider, H., Uhlendorff, A., van den Berg, G.J., Zimmermann, K.F. (2010). Towards Evidence-Based Labour Policy-Making. IZA Discussion Paper no. 5400.

de Jong, S.P.K., Muhonen, R. (2020). Who benefits from ex ante societal impact evaluation in the European funding arena? A cross-country comparison of societal impact capacity in the social sciences and humanities. Research Evaluation, 29(1), 22-33.

Elia, L., Santangelo, G., Schnepf, V.S. (2015). Synthesis report on the Pilot projects to carry out ESF related counterfactual impact evaluations. European Commission: Centre for Research on Impact Evaluation.

European Commission (2012). Design and Commissioning of Counterfactual Impact Evaluations. A Practical Guidance for ESF Managing Authority. Luxembourg: Office for Official Publications of the European Communities.

European Commission (2013a). EVALSED Method and Techniques. Luxembourg: Office for Official Publications of the European Communities.

European Commission (2013b). EVALSED: The resource for the evaluation of SocioEconomic Development. Luxembourg: Office for Official Publications of the European Communities.

European Commission (2014). Guidance Document on Monitoring and Evaluation. The programming period 2014-2020. Luxembourg: Office for Official Publications of the European Communities. 
Gertler, P., Martinez, S., Premand, P., Rawlings, B.L., Vermeersch, M.J.C. (2016). Impact Evaluation in Practice. Washington D.C.: The World Bank.

Ho, D., Imai, K., King, G., Stuart, E. (2007). Matching as Nonparametric Preprocessing for Reducing Model Dependence in Parametric Causal Inference. Political Analysis, 15(3), 199-236.

Jaklič, A. (2012). Evalvacija izvajanja politike podjetništva in konkurenčnosti v obdobju 2004-2009 s predlogi novih ukrepov in kazalnikov ter sprememb obstoječih ukrepov in kazalnikov. Ljubljana: Univerza v Ljubljani, Fakulteta za družbene vede.

Južnik Rotar, L. (2012). How effective is the Slovenian institutional training program in improving youth's chances of reemployment? Eastern European economics, 50(3), 94106.

Južnik Rotar, L. (2019). What are the treatment effects of a work-first participation programme on young unemployed people in the Netherlands? Panoeconomicus, 66(2), 203-217.

Khandker, S. R., Koolwal, G.B., Samad, H.A. (2010). Handbook on impact evaluation: Quantitative methods and practices. Washington, D.C.: The World Bank.Lee, M.J. (2005). Microeconometrics for Policy, Program and Treatment Effects. Oxford: Oxford University Press.

Michalek, J. (2012). Counterfactual impact evaluation of EU rural development programmes - Propensity Score Matching methodology applied to selected EU Member States. Luxembourg: Office for Official Publications of the European Communities.

OPRČV (2008). Operativni program razvoja človeških virov za obdobje 2007-2013. Ljubljana: Služba vlade Republike Slovenije za lokalno samoupravo in regionalno politiko.

OPROPI (2008). Operativni program razvoja okoljske in prometne infrastrukture za obdobje 2007-2013. Ljubljana: Ministrstvo za gospodarski razvoj in tehnologijo.

OPRR (2008). Operativni program krepitve regionalnih razvojnih potencialov za obdobje 2007-2013. Ljubljana: Ministrstvo za gospodarski razvoj in tehnologijo.

Računsko sodišče Republike Slovenije (2008). Revizijsko poročilo: Sistem izvajanja evropske kohezijske politike. Ljubljana: Računsko sodišče Republike Slovenije.

Ravallion, M. (2012). Evaluation in the Practice of Development. The World Bank Policy Research Working Paper Series 4547.

Služba vlade Republike Slovenije za razvoj in evropsko kohezijsko politiko (2016). Poročilo o črpanju sredstev EKS 2007 - 2013 za obdobje januar 2015 - december 2015. Ljubljana: Služba vlade Republike Slovenije za razvoj in evropsko kohezijsko politiko.

Srhoj, S., Lapinski, M., Walde, J. (2020). Impact evaluation of business development grants on SME performance. Small Business Economics. https://doi.org/10.1007/s11187$\underline{020-00348-6}$

Wooldridge, J.M. (2010). Econometric Analysis of Cross-Section and Paned Data. Cambridge, MA: MIT Press.

\section{About the authors}

Laura Južnik Rotar, PhD, is Associate Professor of Economics and Head of Department of Economics at the University of Novo mesto Faculty of Economics and Informatics. She gained a PhD in Economics from the University of Ljubljana, Faculty of Economics. She has published in leading journals: Economic Research, Panoeconomicus and Eastern 
European Economics amongst others. She has been involved in several research projects on both national and European levels. The author can be contacted at laura.juznikrotar@uni-nm.si.

Stanko Trček, MSc, formerly affiliated by Republic of Slovenia Government Office for Development and European Cohesion Policy. He gained a MSc in Business and Management from the University of Novo mesto Faculty of Economics and Informatics. He was engaged in number of EU projects. The author can be contacted at stanko.trcek@gmail.com. 